\title{
Storm deposited pebble and cobble-sized particles in the early Emsian of the Ponta Grossa Formation, Paraná Basin (state of Paraná, Brazil)
}

\author{
Yngve Grahn ${ }^{1}$ \& Elvio Pinto Bosetti ${ }^{2}$
}

\begin{abstract}
Quartzite pebble and cobble-sized particles from an arenaceous siltstone with fine sandstone lenses have been found at two localities in the Campos Gerais region, Apucarana Sub-Basin (Paraná Basin), south Brazil. These particles were first interpreted as glacial diamictites, but their smooth surfaces and surrounding sediments indicate another origin. Two of the pebbles are associated with a small scale hummocky cross stratification in the top layer, and with fine sandstone layers below, which is indicative of currents formed by oscillatory flow. None of the particles show any traces of encrustation, and their morphology suggests they have been formed in a fluviatle environment. The surrounding siltstone is affected by bioturbation and contain brachiopods (Australospirifer). Palynomorphs indicate that these storm deposits were formed during an early Emsian maximum inundation on a transgressive ravinement surface.
\end{abstract}

Keywords: Storm deposited particles, palynomorphs, early Emsian.

Resumo Seixos depositados por tempestades durante o Eoemsiano na Formação Ponta Grossa, Bacia do Paraná (estado do Paraná, Brasil). Seixos de quartzito em siltito arenoso com finas lentes de areia foram encontrados em duas localidades da região dos Campos Gerais do Paraná, sub-bacia de Apucarana, Bacia do Paraná, sul do Brasil. Estes seixos foram inicialmente interpretados como diamicititos glaciais mas suas superfícies lisas e as características sedimentares circumvizinhas indicam outra origem. Dois dos seixos são associados a estruturas do tipo hummocky cross stratification de pequeno porte, o que é indicativo de correntes formadas por oscilação de ondas. Nenum dos seixos mostram traços de encrustação. O siltito que suporta os seixos é afetado por bioturbação e contém braquiópodes (Australospirifer). Palinomorfos indicam que estes depósitos de tempestades foram depositados durante uma inundação máxima do Eoemsiano.

Palavras-chave: seixos depositados por tempestades, palinomorfos, Eoemsiano.

INTRODUCTION Only one publication has mentioned or discussed big pebbles or cobbles in the Ponta Grossa Formation. Soares \& Malanski (1968) described three quartzite particles found in the Ponta Grossa Formation in a well near Franco da Rocha Hospital (= Franco da Rocha in this paper). They interpreted these as glaciogenic diamictites. Another possible explanations, not discussed by these authors, are transport with plants or unidirectional currents. Conglomerates containing gravels $(\leq 1 \mathrm{~cm})$ are well-known from the Furnas Formation (Lange \& Petri 1967, Bigarella \& Salamuni 1967), where they occur at several stratigraphic levels within the sandstones. A similar conglomerate has been mentioned from the Middle Devonian São Domingos Formation sensu Melo 1988 and Grahn 1992 (Lange \& Petri 1967 p. 23). However, in these conglomerates the gravel occurs in an arenaceous matrix of fluviatile or near shore origin, in contrast to the siltstone matrix in which occur the big quartzite particles here described.

LOCALITIES Two localities with big quartzite pebbles and cobble are known from the Ponta Grossa Formation, i.e. Franco da Rocha and Tibagi 2 (Figs. 1 e 2). At both localities the particles occur in sediments deposited during a maximum inundation (MFS - maximum flood surface) in sequence B sensu Bergamaschi \& Pereira (2001). The lithology is an arenaceous siltstone with lenses of fine sandstone.

\section{Franco da rocha}

$\left(25^{\circ} 03^{\prime} 21,43^{\prime \prime} \mathrm{S}, 50^{\circ} 08^{\prime} 10,18^{\prime \prime} \mathrm{W}\right)$

This locality (Figs. 1 e 2 ) was first described by Soares \& Malanski (1968). It is a $12,5 \mathrm{~m}$ deep well constructed for the water supply of a nearby hospital (Fig. 2). Two quartzite pebbles and a cobble occurred about $8 \mathrm{~m}$ from the top, and an estimated $52-53 \mathrm{~m}$ above the Furnas/ Ponta Grossa contact (Fig. 2). No fossils were collected. The sequence probably corresponds to the top of the section at Curva $1\left(25^{\circ} 03^{\prime} 56^{\prime \prime} \mathrm{S}, 50^{\circ} 08^{\prime} 00^{\prime \prime} \mathrm{W}\right)$, described by Bosetti (2004), situated ca. $150 \mathrm{~m} \mathrm{SSE}$ of the Franco da Rocha locality (Fig. 2).

\section{Tibagi 2}

$\left(24^{\circ} 29^{\prime} 51^{\prime \prime} \mathrm{S}, 50^{\circ} 25^{\prime} 00^{\prime \prime} \mathrm{W}\right)$

The locality (Figs. 1 e 2), no longer accessible, was described by Zabini (2007) and Zabini et al. (2010) in pa-

1 - Universidade do Estado do Rio de Janeiro, Faculdade de Geologia, Rio de Janeiro (RJ), Brasil. E-mail: yngvegrahn@gmail.com

2 - Universidade Estadual de Ponta Grossa, Departamento de Geociências, Laboratório de Paleontologia, Ponta Grossa (PR), Brasil.

E-mail: elvio.bosetti@pq.cnpq.br 


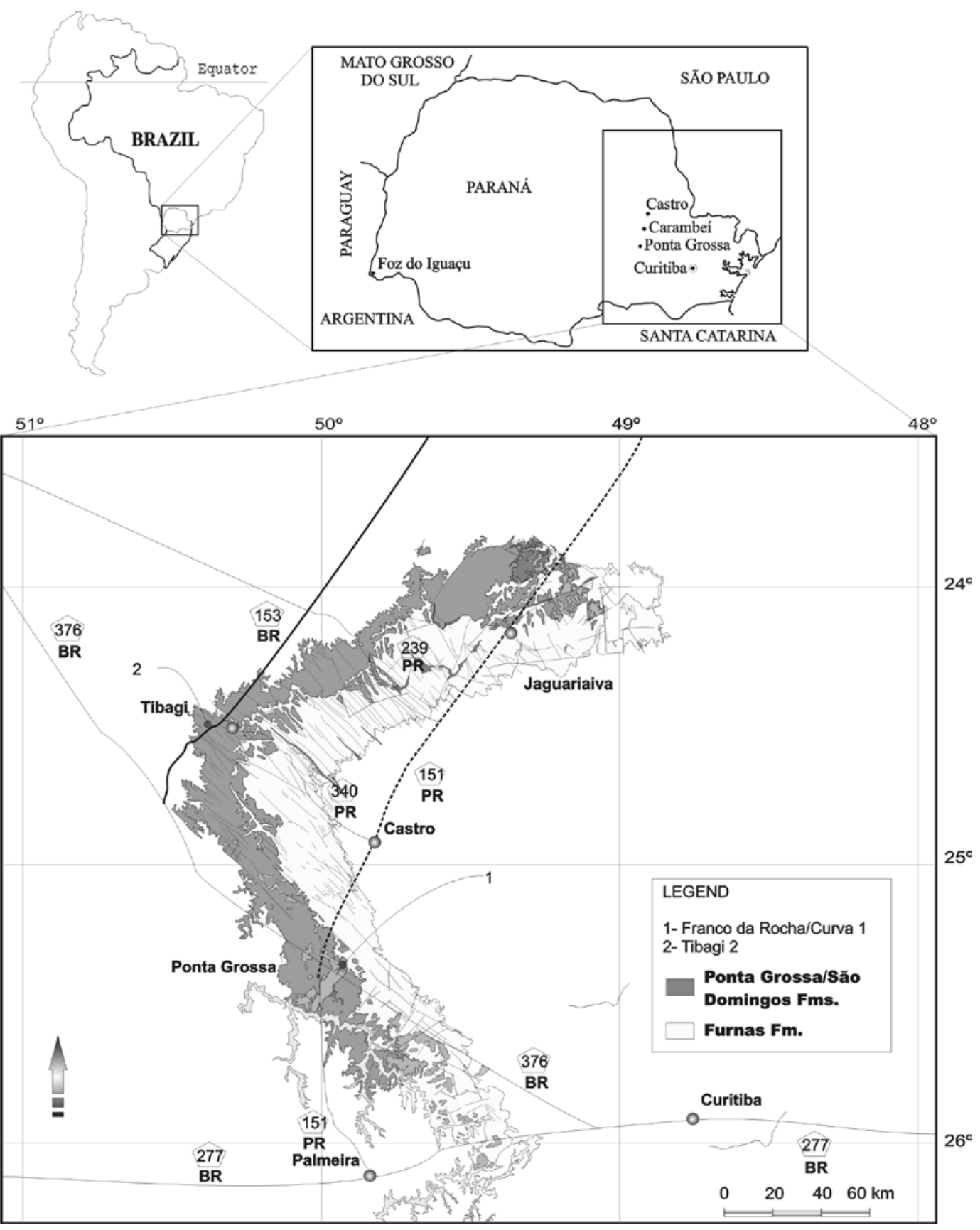

Figure 1 - Location map for the localities investigated.

pers discussing lingulid taphofacies. Two quartzite pebbles were collected from the upper part (Fig. 2), and at an estimated $55 \mathrm{~m}$ above the Furnas/Ponta Grossa contact (Fig. 2). A sample was taken for dating purposes from a horizon stratigraphically above the top layer of Tibagi 2 in an outcrop along the Tibagi - Alto da Amparo road (BR-153). No palynomorphs were encountered.

EVIDENCE FOR STORM DEPOSITION OF THE PEBBLES AND THE COBBLE Altogether four quartzite pebbles and one cobble with a size range between 12.5 and $95 \mathrm{~mm}$ (Fig. 3) are known from the Ponta Grossa Formation, attributed to a maximum inundation surface in the early Emsian (see below).
The occurrences of these particles are scattered and found in a dark arenaceous siltstone with gravel indicating either a transport to their position in the inner shelf or as a result of reworking (Tamura \& Masuda 2005) of earlier sediments (transgressive ravinement surface). The surrounding siltstone contains a benthic fauna dominated by lingulids and bivalves (Bosetti \& Horodyski 2009). The particles are smooth, and there are no glacial striations, encrustation or any eroded remains of encrusting organisms. Their shape suggests they were formed in a fluviatil environment. The brachiopod Australospirifer is associated with the pebbles (Fig. 3J), and this genus characterizes the Marine Benthic Life Zone 3 and/or 4 (Boucot, 1975, personal 


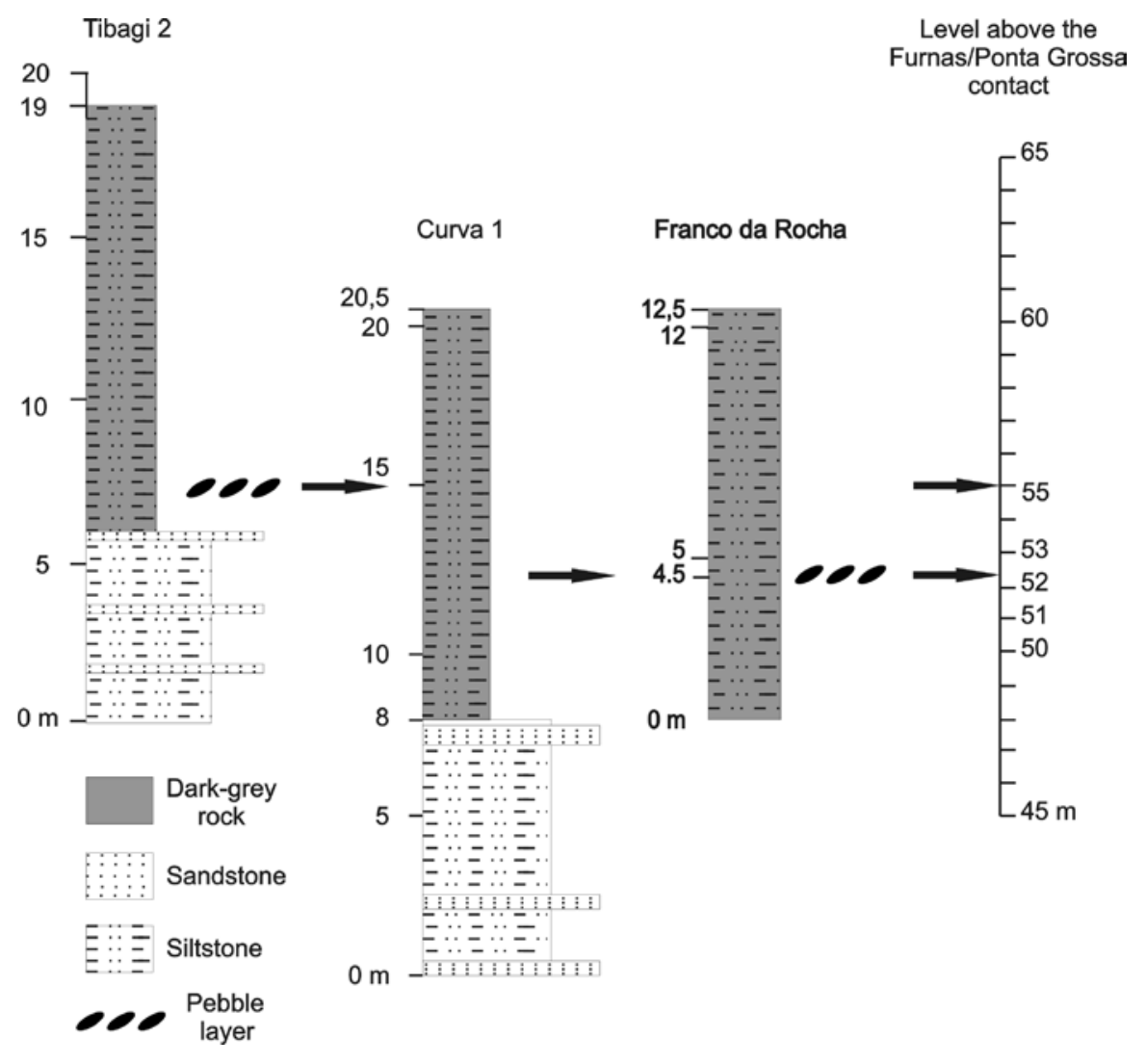

Figure 2 - Lithologic columns for the Tibagi 2, Curva 1, and Franco da Rocha localities.

communication 2009), representative of a shoreface to shallow inner shelf environment, at a depth interval between 15 and 75 to $175 \mathrm{~m}$.

Land plants with roots large enough to transport big pebbles are known from the upper Emsian Fort Prével Member of the Battery Point Formation, Gaspé Bay, Québec, Canada (Elick et al.1998). These plants had rhizomatous roots that penetrated the sandy soils up to a depth of ca. $1 \mathrm{~m}$. If uprooted, such plants could have been transported with riverine pebbles of comparable size to the shoreface. However, the age of the sediments hosting the pebbles in the Ponta Grossa Formation are older than the Battery Point Formation plant-bearing beds. Furthermore, there are no root impressions or any other evidence that suggests this possibility.

Another possibility are currents combined with oscillatory flow. The surface layer containing the big pebbles is irregular and displays a small scale hummocky cross stratification confirming influence of oscillatory movements (Fig. 3K). Hummocky cross stratification is thought to be formed by storm wave surges on the shoreface (Harms et al. 1975). The structure is also considered as diagnostic of inner shelf storm deposits (Swift et al. 1983). Below the hummocky cross stratified layer the beds contain lenses of fine-grained sandstone (Fig. 3K). No truncation surfaces have been observed, and the beds can only be explained by the deposition of sand by a single event.
A strong and highly concentrated unidirectional flow is required to transport the amount of sediments needed (Myrow \& Southard 1991). Beds like those from Tibagi 2 (Figs. 3 I, K) can be produced by flows on slopes with an angle less than $1^{\circ}$ (Carter 1975).

A possibility is that storms eroded the beach sediments and transported the sands to the inner shelf by grain flow, strongly influenced by oscillatory waves (Duke et al. 1991). The gravel, pebbles and the cobble settled on the top of the grain flow through pore pressure when the beds were deposited through frictional freezing (Carter 1975). Modified grain flows with a high concentration and cohesive matrix support and a lift provided with flow turbulence (Enos 1977), or traction carpets, would concentrate larger particles on the top of laminar flows through dispersive pressure (Lowe 1979).

However, we favour an explanation that the pebbles and the cobble in the lower Ponta Grossa Formation were a part of a transgressive ravinement surface and deposited in a shoreface environment, where storm processes completely reworked previous deposits, and redistributed the scattered larger particles on these surfaces. In this case, coarse clasts must form surfaces, even though as scattered pebbles (Souza Cruz personal communication 2009). However, hummocky cross-stratified beds generally are too thick $(>20 \mathrm{~cm})$ to be accounted for by in situ suspension (Swift et al. 

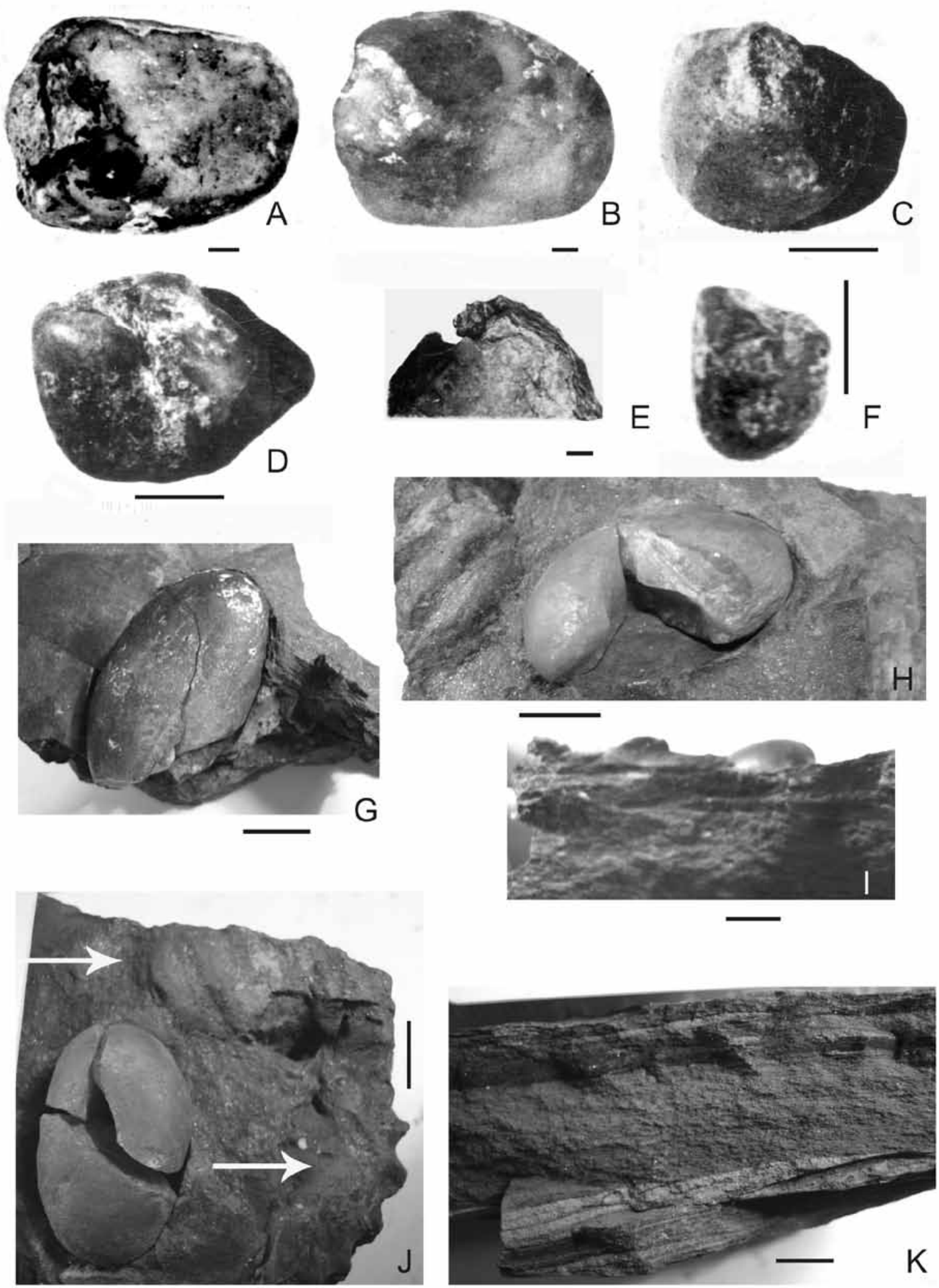

Figure 3 - Quartzite pebbles and associated sedimentary structures from the Ponta Grossa Formation. Figures A-F from Soares \& Malanski (1968). MP! = Museu de Paleontologia-Invertebrados. Ponta Grossa. The scale bar represent $10 \mathrm{~mm}$. A-B) Pebble no. 1 by Soares \& Malanski (1968). Franco da Rocha. C-D) Pebble no. 2 by Soares \& Malanski (1968). Franco da Rocha. E) Detail of pebble no.1. F) Pebble no. 3 by Soares \& Malanski (1968). Franco da Rocha. G) Pebble MPI 1500 from Tibagi 2. H) Pebble MPI 1501 from Tibagi 2. Note the gravel on the surface of the siltstone. I) Side-view of pebble MPI 1500. J) Complete pebble MPI 1501. The arrows points at specimens of Australospirifer. K) Detail of the storm deposit with pebble MPI 1500. Note the $2 \mathrm{~cm}$ thick hummocky cross stratification followed by laminated sedimentation with fine sandstone lenses. 
$1983)$, but in this case they are only $2 \mathrm{~cm}$ thick $(<1 \mathrm{~cm}$ wide). If this is a correct interpretation the reworking took place at a depth of $15 \mathrm{~m}$, or slightly below, according to the incorporated fauna. The closed valves of the Australospirifer specimens suggests they either were in situ or transported a short distance.

AGE OF THE STORM DEPOSITS The base of the maximum inundation (MFS) in sequence B sensu Bergamaschi \& Pereira (2001) has been dated as early Emsian based on spores, acritarchs, and chitinozoans from several localities in the Paraná Basin, e.g. the Jaciara (Mendlowicz Mauller et al. 2007, 2009), Jaguariaiva (Grahn et al. 2000, Mendlowicz Mauller et al. 2009) and Tibagi - Telemaco Borba (Grahn et al. 2000) sections, and the 2-AG-1-MT (Grahn et al. 2000, Mendlowicz Mauller et al. 2009), Paleosul-02-RV-MS (Mendlowicz Mauller et al. 2009), RVR-1 (Gaugris \& Grahn 2006, Mendlowicz Mauller et al. 2009) and 9-PPG-7PR (Gaugris \& Grahn 2006, Mendlowicz Mauller et al. 2009) wells. A sample collected from a road cut (Fig. 1B) of the Tibagi - Alto de Amparo road (BR 153), just above the pebbles at Tibagi 2, did not contain any palynomorphs. Since middle Emsian (AB - FD spore zones) are missing, or very condensed, in the Paraná Basin (Melo \& Loboziak 2003, Grahn 2005) the lower MFS level in sequence B probably corresponds to the uppermost PoW spore Zone.

CONCLUDING REMARKS Particles with a length over $10 \mathrm{~mm}$ are rare in the Ponta Grossa Formation sensu Grahn 1992. Four quartzite pebbles and a cobble with a size range from 12.5 to $95 \mathrm{~mm}$ have been found in two localities at levels corresponding to a maximum inundation (MFS) in sequence B by Bergamaschi \& Pereira (2001). These levels have been dated as early Emsian (uppermost PoW spore Zone). The quartzite pebbles and the cobble occur parallel to the bedding planes in an arenaceous siltstone, and they are perfectly smooth. The deposits are either unidirectional flows, where the top layer displays a small scale hummocky cross lamination, and the layers below fine sandstone lenses. This is characteristic features for a deposition of a current induced and influenced by oscillatory flow action. The pebbles are associated with brachiopods (Australospirifer) from a shoreface to shallow inner shelf environment. If a result of a grain flow the gravel and the pebbles settled on the top of the flow through pore pressure when the beds were deposited through freezing, or through high concentration and cohesive matrix support and a lift provided with flow turbulence and a dispersive pressure. We favour another more likely possibility that the pebbles and the cobble were a part of a transgressive ravinement surface and after the sediments were reworked by storm actions settled on top of the new surface.

Acknowledgements Yngve Grahn thanks the Conselho Nacional de Desenvolvimento Científico e Tecnológico (CNPq, PQ 309751/2007-1), which made his work possible through grants. Thanks are also due to the Faculty of Geology at Universidade do Estado do Rio de Janeiro (UERJ), Prof. Claudia Sayão Valladares, head of the post-graduate program at the Faculty of Geology at UERJ for access to the facilities. Elvio P. Bosetti thanks the Conselho Nacional de Desenvolvimento Científico e Tecnológico (CNPq PQ 480427/2007$0)$ for the financial support and to the Palaios Group/ UEPG/CNPq for the support in the field work. The authors are greatful to Drs. Michael Holz (Universidade Federal da Bahia, Salvador) for comments, and Carlos Emanoel de Souza Cruz (Petrobras, Rio de Janeiro) for suggestions and reading of the manuscript. Comments of an anonymous reviewer greatly improved the content. Prof. emer. Art Boucot (Corvallis, Oregon) checked the English. Our sincere thanks to all.

\section{References}

Bergamaschi S. \& Pereira E. 2001. De Caracterização de seqüências deposicionais de $3^{\circ}$ ordem para o SiluroDevoniano na sub-bacia de Apucarana, Bacia do Paraná, Brasil. Ciên. Técn. Petról. Seção: Explor. Petról., 20:63-72.

Bigarella J.J. \& Salamuni R. 1967. Some palaeogeographic features of the Brazilian Devonian. Bol. Paran. Geociênc., 21/22:133-151.

Bosetti E.P. 2004. Tafonomia de alta resolução das fácies de offshore da sucessão devoniana da região de Ponta Grossa - Paraná, Brasil. Unpublished Ph.D. Thesis, Universidade Federal do Rio Grande do Sul, Porto Alegre, $137 \mathrm{p}$.

Bosetti E.P. \& Horodyski R.S. 2008. Distribuição da macropaleofauna devoniana na seção colunar Tibagi - Alto do Amparo, Tibagi, Estado do Paraná, Brasil. In: SBG, Cong. Bras. Geol., 44, Curitiba, Anais, p. 787.

Boucot A. 1975. Evolution and extinction rate controls.
Amsterdam, Elsevier, 427 p.

Carter R.M. 1975. A Discussion and Classification of Subaqueous Mass- Transport with Particular Application to Grain-Flow, Slurry-Flow and Fluxoturbidites. Earth Scien. Rev., 11:145-177.

Duke W.L., Arnott R.W.C., Cheel R.J. 1991. Shelf sandstones and hummocky cross-stratification: New insights on a stormy debate. Geology, 19:625.

Elick J.M., Driese S.G., Mora C.I. 1998. Very large plant and root traces from the Early to Middle Devonian: Implications for early terrestrial ecosystems and atmospheric $\mathrm{p}\left(\mathrm{CO}_{2}\right)$. Geology, 26:143-146.

Enos P. 1977. Flow regimes in debris flow. Sedimentol., 24:133-142.

Gaugris K.A. \& Grahn Y. 2006. New chitinozoan species from the Devonian of the Paraná basin, south Brazil, and their biostratigraphic significance. Ameghiniana, 43:293-310. 
Grahn Y. 2005. Devonian chitinozoan biozones of Western Gondwana. Acta Geol. Polon., 55:211-227.

Grahn Y., Pereira E., Bergamaschi S. 2000. Silurian and Lower Devonian chitinozoan biostratigraphy of the Paraná Basin in Brazil and Paraguay. Palynol., 24:143172.

Harms J.C., Southard J.B., Spearing D.R., Walker R.G. 1975. Depositional environments as interpreted from primary sedimentary structures and stratification sequences. Soc. Econ. Paleon. Min. Short Course 2, 161 p.

Lange F.W. \& Petri S. 1967. The Devonian of the Paraná Basin. Bol. Paran. Geociênc., 21/22:5-55.

Lowe D.R. 1979. Sediment gravity flows: their classification and some problems of application to natural flows and deposits. SEPM Spec. Publ., 27:75-82.

Melo J.H.G. 1988. The Malvinokaffric Realm in the Devonian of Brazil. In: McMillan N.J., Embry A.F., Glass D.J. (eds.) Devonian of the World. Canadian Soc. Petrol. Geol. Mem.,14:669-703.

Melo J.H.G. \& Loboziak S. 2003. Devonian - Early Carboniferous biostratigraphy of the Amazon Basin, northern Brazil. Rev. Palaeobot. Palynol.,124:131-202.

Mendlowicz Mauller P., Machado Cardoso T.R., Pereira E., Steemans P. 2007. Palynostratigraphic results on the Devonian of the Alto Garças Sub-basin (Paraná Basin Brazil). In: Carvalho I. de S., Cassab R.C.T., Schwank C., Carvalho M.A., Fernandes A.C.S., Rodrigues M.A. da C., Carvalho M.S.S., Arai M., Oliveira M.E.Q. (Portuguese Editors) Paleontologia: Cenários de Vida. Rio de Janeiro, Editora Interciência Ltda, 2:607-619.

Mendlowicz Mauller P., Grahn Y., Machado Cardoso T.R. 2009. Palynostratigraphy from the Lower Devonian of the Paraná Basin, south Brazil, and a revision of contemporary chitinozoan biozones from western Gondwana. Stratigraphy, 6:313-332.

Myrow P.M. \& Southard J.B. 1991. Combined-flow model for vertical stratification sequences in shallow marine storm-deposited beds. J. Sedimen. Petrol., 61:202-210.

Soares O \& Malanski E. 1968. Nota sobre a ocorrência de Seixos nos folhelhos Ponta Grossa. Faculdade Estadual de Filosofia Ciências e Letras de Ponta Grossa. Geologia v.1, 6 p.

Swift D.J.P., Figueiredo A.G., Freeland G.L., Oertel G.F. 1983. Hummocky cross stratification and megaripples; a geological double standard? J. Sedimen. Petrol., 53:1295-1317.

Tamura T. \& Masuda F. 2005. Bed thickness characteristics of inner shelf storm deposits associated with a transgressive to regressive Holocene wave-dominated shelf, Sendai coastal plain, Japan. Sedimentol., 52:1375-1395.

Zabini C. 2007. Lingulídeos da Sucessão Devoniana da Bacia do Paraná, região dos Campos Gerais, Brasil: Revisão de conceitos Biológicos-Ecológicos e análise tafonômica básica. Unpublished M.Sc. Thesis, Universidade Federal do Rio Grande do Sul, Porto Alegre, 130 p.

Zabini C., Bosetti E.P., Holz M. 2010. Lingulid taphofacies from the Devonian succession, Paraná Basin, Brazil. Palaeogeography, Palaeoclimatology, Palaeoecology, 292:44-56.

Manuscrito ID 14790

Submetido em 16 de julho de 2009 Aceito em 15 de março de 2010 